\title{
THE ROLE OF PUBLIC AUTHORITIES DURING MOBILIZATION
}

\author{
Alexandru STOIAN \\ "Nicolae Bălcescu" Land Forces Academy, Sibiu, Romania \\ alex_stoian@yahoo.com
}

\begin{abstract}
Imposed by states in order to defend its own territory and national values during the time of crisis, mobilization of armed forces in a contemporary global context creates new challenges for the public authorities, designers of the national legal framework and for the military authorities. In this regard, extraordinary measures can be taken in political, economic, social, administrative, diplomatic, legal and military fields, planned and prepared in peacetime. The Romanian National Defense System consists of the forces intended for defense, the resources of the national defense and the territorial infrastructure and provides a stable foundation for all types of actions related to mobilization, as long as the procedures involved are implemented at a high level of efficiency.
\end{abstract}

Keywords: mobilization, military, public administration, law

\section{Mobilization of armed forces in a contemporary global context}

Perceived as one of the most significant forms of global evolution of the $20^{\text {th }}$ century, the regional defense cooperation has created a novel perspective on the international relationships and a solid base for multilateral integration of states' national interests. In order to create a better level of stability and peace, vital for safeguarding the national values, the national defense system of the state has turned into an indispensable instrument for ensuring peace.

The larger influence of globalization and the increase of the transnational activities determine countries to interact with both state and non-state actors. In some critical situations related to war, terrorist networks, cyber-attacks or major natural disasters, the global character of the threat demands a multinational form of the response, in which each country members are involved. Whatever the materialization of the menace, collective regional structures and efficient applicable procedures are vital concerning possibilities of national and international crisis occurrence.

Since it was founded in 1949 as a counterweight to the Soviet Union, the North Atlantic Treaty Organization has had a crucial role in establishing the regional framework in order to preserve peace and strength of the regional security. One of the most cited and debatable articles, Article 5, establish the principle that an attack on one member of NATO is basically an attack on all members of the organization.

"The Parties agree that an armed attack against one or more of them in Europe or North America shall be considered an attack against them all and consequently they agree that, if such an armed attack occurs, each of them, in exercise of the right of individual or collective self-defense recognized by Article 51 of the Charter of the United Nations, will assist the Party or Parties so attacked by taking forthwith, individually, and in concert with the other Parties, such action as it deems necessary, 
including the use of armed force, to restore and maintain the security of the North Atlantic area." [1]

\section{Romanian legal framework applicable to mobilization}

In order to highlight the support of democratic control over the defense forces and national resources available for mobilization, the Constitution of Romania, a fundamental law, states that the army is exclusively subordinated to the will of the people and contributes to collective defense in the military alliance systems, according to the law and to the international treaties Romania is a party to: "The Army shall be exclusively subordinated to the people's will, in order to guarantee the sovereignty, independence and unity of the State, the country's territorial integrity, and the constitutional democracy. Under the law and the international treaties Romania is a party to, the Army shall contribute to the collective defense in military alliance systems, and participate in peace keeping or peace restoring missions." [2]

According to the Law no. 45/1994 of the national defense, the national defense comprises the set of measures and activities adopted and carried out by the Romanian state in order to "guarantee the national sovereignty, independence and unity of the state, the territorial integrity of the country and the constitutional democracy, and the fulfillment of these activities is ensured by the public authorities, according to the competencies established by law". [3]

The Romanian National Defense System consists of the forces intended for defense, the resources of the national defense and the territorial infrastructure, elements over which the management provided by the most important state authorities is exercised. Subsequently, article 7 of the Law on National Defense, specifies that the leading of the national defense system is an exclusive and inalienable power of the constitutional authorities of the state and is conducted by Parliament, President of
Romania, Supreme Council of National Defense, Government of Romania, Ministry of Defense and authorities of public administration with responsibilities in the field of national defense.

As a permanent requirement of contemporary democracies, the effective control over national defense system is represented by the division of the exclusive political, administrative and military command and the assignation of separate tasks to the major public authorities of the state.

The mobilization is regulated by the Law no. 355/2009 on partial or total mobilization of armed forces and state of war. In a extensive definition, asserted by the law, mobilization represents "all the extraordinary measures that can be taken in political, economic, social, administrative, diplomatic, legal and military fields, planned and prepared in peacetime[...], to the appearance or imminence of a serious threat that may affect sovereignty, independence and unity of the state, the territorial integrity of the country and constitutional democracy." [4] A very important support element of the entire process of mobilization consists in the management of the public resources and there are a large number of regulations and legal procedures in this area. The public administration authorities elaborate the plan for mobilization of national defense economy, with the specific objective to satisfy not only the demands of the products and services required by the forces of the national defense system, but also the interests of public institutions and the economic operators, as well as to ensure the rational consumption for the population. This legal aspect, provided by Law no. $477 / 2003$ on preparation of the national economy and the defense territory [5], illustrates one of the very complex phases of the mobilization: the preparation of the national economy and the territory for defense involving a set of measures and actions that are established and carried out in peace time. 


\section{The procedure for declaring mobilization}

Romanian legal framework empowers both the Parliament and President of the Republic to decide the necessity of the mobilization. Thus, Law no. 355/2009 establishes that Parliament decides partial or total mobilization, and also demobilization. The legislative, also, approves or rejects, as the case may be, the decree of the President of Romania declaring partial, total mobilization or demobilization. [6]

The President of Romania may declare, with the prior approval of Parliament, by decree, countersigned by the Prime Minister, mobilization or demobilization, and, if it is necessary, the armed forces designated for defense. Only in exceptional cases, the President's decision is later subject Parliament's approval, within 5 days of adoption.

It is mandatory that Parliament's decision to declare mobilization or the decree of the President of Romania shall be published immediately in the Official Gazette of Romania, Part I.

The decision of the Parliament or the decree of the President of Romania is promptly transmitted to the Government and other public authorities with defense and national security responsibilities in order to take direct measures and to apply the administrative and military procedures. At the same time, the decision of the Parliament or the decree of the President of Romania is publicly announced by all types of mass media to inform the population immediately and correctly.

A comparable procedure is applied in case of demobilization, which is the resignation of the measures and activities undertaken to mobilize, as a result of ceasing the action of the factors that generated the mobilization and the absence of other factors that would impose the maintenance of partial or total mobilization. Demobilization is declared by the public authorities empowered by the Constitution of Romania, at the proposal of the Supreme Council of Defense of the Country.

\section{Romanian mobilization system}

In order to guarantee the national sovereignty of Romania, the independence and the unity of the state, the territorial integrity of the country and the constitutional democracy, Law no. 355/2009 enforces a national mobilization system, which is composed of management and execution structures, resources, infrastructure and related relations.

The command of the national mobilization system is an exclusive attribute of the constitutional authorities of the state and comprises the Parliament, the President of Romania, the Supreme Council of Defense, the Government and other public authorities with powers in the field of national defense and security, according to the attributions established by laws.

An important role is carried out by the Ministry of National Defense which coordinates the planning and evaluation of the preparations for the mobilization of the forces and monitors the execution of activities through the Defense General Staff Even if the responsibility of the mobilization of the forces is supported by each institution with attributions in the field, the command of the mobilization of the armed forces is the attribute of the Chief of the Defense General Staff and is carried out at the strategic level of the Mobilization Command Center, established in the Defense General Staff, through the Central Group of mobilization leadership. [7]

At the executional level, the national mobilization system consists of forces for defense, public authorities, deconcentrated public services and community services, economic operators whose activities are directly related to the provision of resources needed to mobilize.

Juridically speaking, the military authorities can control a very wide range of issues during mobilization and they have the power to regulate different aspects during 
the period of mobilization applying military ordinances, a form of legal acts that empowers military authorities to deal with all types of situations by substitute the prerogatives of central or local public authorities. Therefore, some attributions of the central public administration authorities and of the local public administration authorities may be transferred to the competence of the military authorities.

In this particular case, the military authorities may order special measures according to their attributions and responsibilities, measures which can infringe fundamental rights, according to Government Emergency Ordinance no. 1/1999 on the regime of the state of siege and the regime of the state of emergency state. Consequently, military authorities could limit or prohibit the movement of vehicles or persons in certain areas or between certain hours, the participation to public meetings, demonstration and marches, the use of weapons. Other measures refers to the protection of military information intended to be communicated through the media, the temporary closure of petrol stations, restaurants, clubs, headquarters of associations and other public institutions, the temporary suspending of the issue or broadcast of publications or broadcasts of radio or television stations. [8]

"All these measures are restrictive and may have a major impact on the free exercise of fundamental rights. Their establishment can only be justified by the need to limit threats that seriously jeopardize the sovereignty, independence, unity or territorial integrity of the state" [9]

\section{Mobilization plan for national economy}

Another significant role of public authorities related to mobilization is the preparation of the national economy and the territory for defense by implementing a set of measures and actions that are established and carried out in peace time.
The Government is responsible for this action and it ensures the application of the measures related to specific areas, according to the law, to the decisions of the Parliament and of the Supreme Council of Defense.

In the event of mobilization or war, the Government shall establish the priorities for contracts and allocate resources to meet the urgent requirements needed to support the defense effort. [10]

The plan to mobilize the national defense economy represents a set of measures and actions for the transition from the state of peace to the state of war and its operation in order to provide the resources needed to support the defense effort. The mobilization plan includes mandatory responsibilities and tasks for the ministries, central and local administrative public authorities and other institutions and economic operators.

The preparation of the national defense economy refers to the identification of defense capabilities and to the establishment, creation and maintenance of mobilization reserves. The priorities for carrying out these tasks of the mobilization plan determine the ranking of objectives, according to their importance, in support of the defense effort and for which the necessary resources are allocated.

Therefore, defense capabilities are the production lines or specialized services, the assets they serve, the specific technological arrangements existing in the fields of industry, transport, communications and information technology, health care, as well as storage facilities for state and mobilization, in order to fulfill the vital needs of the forces of the national defense system in the event of mobilization.

\section{Conclusions}

The national defense represents one of the most important pillars of the state edifice, and, for achieving its goals, it uses legal, managerial and political processes in order to accomplish the government's mandate.

The subsystem of the public administration, 
which carries out, during peacetime, the concrete execution of the normative acts into the military field, the military administration, ensures the organization, maintenance, completion and mobilization of the armed forces, as well as the elaboration of the specific rules for the application of the legislation and of the normative acts in the army. Moreover, in situations of crisis or war, the military administration, through military authorities, is the one that ensures the organization and the ruling, of an occupied territory or ensures the carrying out of specific tasks under exceptional circumstances, such as the state of siege or war.

The imperative requirement for ensuring the peace in the region has become an essential responsibility for the states, and the development and consolidation of democracy, the preservation of the rule of law and the respect for human rights and fundamental freedoms cannot be achieved without a robust juridical system in which fundamental democratic values are ruled by efficient legal framework.

Mobilization of armed forces in a contemporary global context creates new challenges both for the public authorities, designers of the national legal framework and for the military authorities which implement directly the legal procedures.

Reflecting the commitments of the geopolitical environment, Romanian mobilization framework could provide a reliable legal base for all types of actions related to mobilization, as long as the procedures that derive from the legal core are implemented and conducted at a high level of professionalism.

\section{References}

[1] The North Atlantic Treaty, Washington D.C. 4 April 1949, art.5 https://www.nato.int/cps/ic/natohq/official texts 17120.htm.

[2] Constitution of Romania, amended and completed by Law for the revision of the Constitution of Romania no. 429/2003, published in the Official Journal of Romania, Part I, no. 758 of 29 October 2003, art. 118, alin. 1.

[3] Law no. 45/1994 of the national defense, published in the Official Journal of Romania, Part I, no. 172 of 7 July 1994, art.1.

[4] Law no. 355/2009 on state of partial or total mobilization of armed forces and state of war, published in the Official Journal of Romania, Part I, no. 805 of 25 November 2009, art. 2.

[5] Law no. 477/2003 on preparation of the national economy and the defense territory, republished in the Official Journal of Romania, Part I, no. 201 of 21 March 2014, art.8.

[6] Law no. 355/2009 on state of partial or total mobilization of armed forces and state of war, art. 6

[7] Ibidem, art.7.

[8] Government Emergency Ordinance no. 1/1999 on the regime of the state of siege and the regime of the state of emergency, published in the Official Journal of Romania, Part I, no. 22 of 21 January 1999, approved with amendments and completions by Law no. 453/2004, published in the Official Journal of Romania, Part I, no. 1052 of 12 November 2004, art.20.

[9] Floarea Şerban, Starea de asediu, starea de urgenţă. Regim juridic, doctrină, legislaţie, drept comparat, Bucureşti, Editura Militară, 2005, 74.

[10] Law no. 477/2003 on preparation of the national economy and the defense territory, art.9. 